\title{
Yaşlı Yetişkinlerde Fonksiyonel Uygunluk: 60 - 94 Yaş Arası Normal ve Fazla Kilolu Yaşlı Yetişkinlerin Fonksiyonel Uygunluklarının Karşılaştırılması
}

\author{
Functional Fitness for Older Adults: Comparison of Functional Fitness of Normal \\ Weight and Overweight Older Adults between the ages of 60-94
}

${ }^{1-2}$ Ebubekir AKSAY

${ }^{1}$ Almanya TV Eberbach e.V. Sağlık, Rehabilitasyon ve Engelli Sporları Bölümü

${ }^{2}$ Gelişim Üniversitesi, Beden Eğitimi ve Spor Yüksekokulu

\section{Yazışma Adresi \\ Corresponding Address:}

\section{Dr. Ebubekir Aksay}

\section{ORCID No: 0000-0002-5706-6698}

Almanya TV Eberbach e.V. Sağlık, Rehabilitasyon ve Engelli Sporları Bölümü

Gelişim Üniversitesi, Beden Eğitimi ve Spor Yüksek Okulu

E-posta: dshs_sr@yahoo.de

Geliş Tarihi (Received): 29.11.2020

Kabul Tarihi (Accepted): 01.09.2021

\section{öz}

Bu çalışmanın birinci amacı 60 - 94 yaş arası yaşlı yetişkinlerin Senior Fitness Test (SFT) sonuçlarının Vücut Kütle İndeksi (VKi) ve yaş gruplarında cinsiyete göre, ikinci amacı elde edilen STF sonuçlarının standart norm değerleri ile karşılaştırmasıdır. Araştırmaya yaşları 6094 arasında olan toplam 273 yaşlı yetişkin birey katılmıştır. VKi değerleri $25 \mathrm{~kg} / \mathrm{m} 2$ altında olan 151 (71 kadın, 80 erkek) birey normal kilolu ve 25 kg/m2 üzeri olan 122 (70 kadın, 52 erkek) birey fazla kilolu grubunu oluşturmuştur. Çalışmada tıbbi muayene gerekmeden kısa sürede uygulanabilen kas kuvveti, aerobik dayanıklılık, çeviklik/dinamik denge ve esneklik ölçümleri yapan ve altı farklı test parametresinden oluşan SFT kullanılmıştır. Çarpıklık basıklık değerleri ile normallik analizi yapılan veriler normal dağılım gösterdiği için bağımsız iki grup karşılaştırmasında bağımsız örneklem t-testi, bağımsız ikiden fazla grubun karşılaştırımasında tek yönlü varyans analizi ve yaş grupları arasındaki farkın kaynağının belirlenmesi için post hoc testlerinden Bonferroni testi kullanılmıştır. Elde edilen veriler esneklik gerektiren testlerde kadınların daha yüksek değerlere ulaştığını, kuvvet, dayanıkııık, çeviklik/beceri gerektiren testlerde erkeklerin ölçüm değerlerinin daha yüksek olduğunu, ilerleyen yaş ile beraber incelenen performans değerlerinin düştüğünü, düşüşün özellikle 70 yaş üzeri grupta üst seviyeye ulaştığını; bacak kuvveti, kol kuvveti, dayanaklıık ve esneklik özelliklerinde artan yaş ile birlikte normal ve fazla kilolu gruplar arasında istatiksel olarak anlamlı farklılık olduğunu göstermektedir $(p<0,05)$. Esneklik gerektiren testlerde kadınlar daha yüksek değerlere ulaşırken, kuvvet, dayanıklılık, çeviklik/beceri gerektiren testlerde erkeklerin ölçüm değerlerinin daha yüksek olduğu belirlenmiştir. Sonuçlar yaşlı yetişkinlerin fiziksel uygunluk değerlendirmeleri için önemli ipuçları vererek, fazla kilonun fiziksel performans üzerine olumsuz etki yaptığını ve katılımcıların testlerin büyük bölümünde standart norm değerlerinin altında kaldığını göstermektedir.

Anahtar Kelimeler: SFT, Fonksiyonel test, Fazla kilo, Hareketlilik, Fonksiyonel uygunluk

\section{ABSTRACT}

The aim of the study is to compare the Senior Fitness Test (SFT) results of older adults aged 60 to 94 with body mass index (BMI) and the obtained STF results by age groups and gender with standard norm values. A total of 273 older adult aged between 60-94 participated in the study. 151 ( 71 women, 80 men) older adult with BMI values below $25 \mathrm{~kg} / \mathrm{m} 2$ constituted the normal weight group and 122 (70 women, 52 men) older adult with BMI values above $25 \mathrm{~kg} / \mathrm{m} 2$ constituted the overweight group. In the study, SFT, which consists of six different test parameters and measures muscle strength, aerobic endurance, agility/dynamic balance and flexibility, and can be applied in a short time without the need for medical examination was used. Since the data analyzed for skewness - kurtosis and normality analysis showed normal distribution, the independent sample t-test was used in the comparison of two independent groups, one-way analysis of variance in the comparison of more than two independent groups, and the Bonferroni test, one of the post-hoc tests, to determine the reason of the difference in source. The data obtained show that the performance decreases with the increasing age, the decline reaches the upper level especially in the group above the age of 70, and there is a statistically significant difference between the groups in terms of leg strength, arm strength, endurance and flexibility with increasing age $(p<0.05)$. The results give important clues for the elderly's physical fitness assessments, showing that excess weight has a negative impact on physical performance and that participants fall below standard norm values in most of the tests. According to these results, it is assumed that excess weight will negatively affect achieving standard norm values.

Keywords: SFT, Functional test, Overweight, Mobility, Functional fitness

Yazar notu: Bu çalışmayı vefatından önce desteğini esirgemeyen değerli hocam, meslektaşım ve dostum Horst Stohkendl'in aziz hatırasina atfediyorum. 
Yaşlı Yetişkinlerde Fonksiyonel Uygunluk: 60 - 94 Yaş Arası Normal ve Fazla Kilolu Yaşlı Yetişkinlerin

Fonksiyonel Uygunluklarının Karşılaştırılması

Functional Fitness for Older Adults: Comparison of Functional Fitness of Normal Weight and Overweight

Older Adults between the ages of 60-94

\section{GíRIŞ}

Yaşlı nüfus oranındaki artış, fazla kilo ve obezitenin dünyanın birçok ülkesinde sorun teşkil ettiği görülmektedir (DOSB, 2016). Dünya Sağlık Örgütü’nün (DSÖ) belirlediği referans aralıklarına göre Vücut Kütle İndeksi (VKİ) 18,5 ile $25 \mathrm{~kg} / \mathrm{m} 2$ arası normal kilolu, $25-30 \mathrm{~kg} / \mathrm{m} 2$ arası fazla kilolu ve $30 \mathrm{~kg} / \mathrm{m} 2$ ve üzeri obez olarak tanımlanmaktadır (WHO, 2000). Bu referans değerlerine göre Alman erkek nüfusunun \%67,1'inin ve kadın nüfusunun \%53'ünün fazla kilolu olduğu (Kurth, 2012) ve Alman yetişkin nüfusunun ortalama \%18'inin obez olduğu belirtilmektedir (Schienkiewitz ve diğ., 2017). Fazla kilo ve obezite birçok sağlık sorununu beraberinde getirmekte ve DSÖ tarafından başlı başına bir hastalık olarak kabul edilmektedir (WHO, 2000). Fazla kilo ve obezitenin tip 2 diyabet (Abdullah, 2010), koroner kalp hastalıkları (Guh ve diğ., 2009; Loellgen ve Loellgen 2011) inme, metabolik bozukluklar, kas-iskelet sistemi bozuklukları ve kanser gibi bazı hastalıkların oluşma riskini arttırdığı (WCRF, 2007), aynı zamanda uyku bozukluklarına ve solunum güçlüklerine neden olabileceği belirtilmektedir (Sherrill ve diğ., 1998). Genetik faktörlerin yanı sıra eğitim durumu ve sosyokültürel farklılıklar gibi dış etkenler obezitenin oluşmasına zemin hazırlarken (Menzinkt ve diğ., 2005), yanlış beslenme ve hareketsizlik en önemli etken olarak gösterilmektedir (WHO, 2013).

Fazla kilo ve obezitenin yanı sıra yaşlanma da olumsuz bir değişim olarak değerlendirilmektedir (Kosel ve Froböse, 1999). Cinsiyetler arasındaki farklılıklar, doğum ve ölüm oranları arasındaki dengesizlikler, ülke içinde yaşayan yabancı kökenli bireylerin oranları vb. demografik değişimlerin toplumlarda giderek sorun haline geldiği ve yaşlı nüfusu arttırdığ 1 düşünülmektedir. Dünya genelinde yaşlı yetişkin sayısının artması hem ekonomik yönden hem de sağlık yönünden risk faktörü oluşturabilmektedir (Rikli ve Jones, 2013b). Alman İstatistik Kurumu’nun verilerine göre 2012 y1lanından sonra Almanya'da doğum oranlarının düştüğü, 1990 yılından sonra 70 yaş üzeri yaşlı yetişkin sayısının 8 milyondan 12 milyona yükseldiği görülmektedir (Statistisches Bundesamt, 2019). Alman yaş ortalamasındaki artış sağlığı tehdit eden bir gelişme olarak değerlendirilirken, sağlıklı yaşlanmanın yollarının aranmaya başlandığı görülmektedir (Aksay, 2021). Sağlıklı yaşlanma bilişsel ve fiziksel işlevselliği koruyan ve sosyal hayata aktif bir şekilde katılımı sağlayan çok boyutlu bir süreç olarak değerlendirilirken (Rowe ve Kahn 1997), yanlış beslenme ve hareketsizlik ile oluşan fazla kiloların özellikle yaşlı yetişkinlerin günlük yaşam kalitesini düşürerek, dışa bağımlılığı arttıracağı ve fonksiyonel performansı azaltacağı belirtilmektedir (Aksay, 2021).

Biyolojik yönden kaçınılmaz ve zorlu bir süreç olarak değerlendirilen yaşlanmanın kuvvet, dayanıklılık, sürat, koordinasyon, çeviklik, denge ve esneklik gibi fiziksel performans bileşenlerini olumsuz etkilediği ve bilgilerin alınması, değerlendirilmesi ve uygulanması gibi bilişsel işlevlerde düşüşe neden olacağı belirtilmektedir (Kubesch, 2007). İlerleyen yaş ile beraber bireylerin daha yavaş düşündüğü ve daha yavaş hareket ettiği gözlenirken (Davi, 2018), yaşl1 yetişkinlerde bilişsel işlev kaybı oluşabileceği (Oswald ve diğ., 2006) ve bu kayıplara bağlı olarak fiziksel performansın düşük olabileceği belirtilmektedir (Allmer, 2005; Newton ve diğ., 2009). Performans kayıplarının sadece yaşlılıkla ilişkilendirilmemesi gerektiği, ancak yaşlanmanın önemli bir etken olduğu belirtilmekte ve insan organizmasının her yaşta, yaşa uygun olarak antrene edilebilir yeterlilikte olduğu vurgulanmaktadır (Aksay, 2013; Chodzko- Mason ve diğg., 2016; Zajko ve diğ., 2009). Bu bağlamda yaşlı yetişkinlerin egzersiz uygulamalarında yaşlanmayı yavaşlatma, dayanıklılık, kuvvet, esneklik ve dengenin korunması ve buna bağlı olarak günlük ihtiyaçların bağımsız bir şekilde karşılanabilmesi öncelikli hedefler arasında yer aldığı görülmektedir (Rikli ve Jones, 2013b; Roaldsen ve diğ., 2014; Wessel ve Hummel, 2019;). Özellikle kas kuvveti ve dayanıklılığın beraber antrene edilmesi gerektiği düşünülmektedir (Aksay, 2021). 50 yaşından itibaren ortalama olarak her geçen on yıl için kas kuvveti \%15-20 oranında düşmekte ve kas kuvvetindeki azalma özellikle günlük yaşam kalitesini düşürerek birçok zorluğu beraberinde getirebilmektedir (DOSB, 2016). Yapılan çalışmalar düzenli ve hedefli bir şekilde yapılan kuvvet antrenmanları ile kas kuvvetinin ilerleyen yaşa 
rağmen geliştirilebilir olduğunu gösterirken (Granacher ve diğ., 2009; Holviala ve diğ., 2006; Macaluso ve De Vito, 2004; Newton ve diğ., 2002), yaşın 90 üzeri olması durumunda dahi kuvvet gelişimin sağlanabileceği belirtilmektedir (Fiatrone, 1990). Yaşlı yetişkinler ile yapılan kuvvet antrenmanlarının hem genel sağlığın korunması hem de kas kuvvet gelişiminin amaçlanması ve özellikle yaşlanma ile artan düşme tehlikesine karşı kasların yeterli kuvvette olması gerektiği vurgulanmaktadır (Conzelmann ve Blank, 2009; Puthoff ve Nielsen, 2007). 30 yaşından itibaren her geçen on yll için dayanıklılığın \%5-15 oranında azaldığı düşünüldüğünde (DOSB, 2016), farklı zorluk derecelerindeki günlük aktiviteleri yapabilmek için belirli düzeydeki kas kuvveti kadar dayanıklılığın da gerekli olduğu belirtilmektedir (Chmelo ve diğ., 2015; Zimmermann, 2000). İlerleyen yaş ile beraber hareket temposunda düşüş yaşanmasına rağmen 65 yaş sonrası dayanıklılık gelişiminin imkânsız olmadığı belirtilmektedir (Conzelmann ve Blank, 2009). Kuvvet ve dayanaklığa ek olarak oluşabilecek esneklik kaybının hareketlilik için gerekli olan birçok fiziksel fonksiyonu engelleyerek ilerleyen yaş ile beraber eklem yaralanma riskini ve hareket sırasında düşme tehlikesini arttırdığı görülmektedir (DOSB, 2016). Aynı zamanda motor öğrenme ve becerinin hareket sırasında yön değiştirmede önemli bir etken olduğu ve günlük yaşamda yapılan herhangi bir iş sırasında ani yön değiştirmelerde yaşlı yetişkinlerin sakatlanmalarını önlenmek için önem taşıdığı belirtilmektedir (DOSB, 2016). Ancak motor öğrenme ve beceri özelliklerinin yaşam boyunca nispeten sabit kaldığı ve motor öğrenme yeteneğinin yaşlanmadan ziyade, geçmiş spor deneyimine bağlı olduğu vurgulanmaktadır (Wollny, 2006).

Dünya genelinde yaşlı nüfusun, obezite ve obeziteye bağlı hastalıkların arttığı ve hareketsiz bir yaşam tarzının daha çok benimsendiği düşünüldüğünde, 60 yaş üstü yaşlı yetişkinlerle yapılacak olan araştırmaların yaşam kalitesini olumlu yönde etkileyeceği düşünülmektedir.

Günümüze kadar yapılan çalışmalarda 60 yaş üstü yaşlı yetişkinlerin fiziksel uygunluklarındaki farkl1lıklar belirtilmesine rağmen VKİ, yaş grupları ve cinsiyete göre karşılaştırmaların sınırlı şekilde birlikte değerlendirildiği görülmektedir. Diğer yandan günümüz literatüründe VKİ, yaş grupları ve cinsiyete bağlı SFT norm değerlerini karşılaştırmaya yönelik oldukça sınırlı bilgi bulunmakta ve bu parametreler arasındaki ilişkinin henüz netleşmediği görülmektedir. Bu düşüncelerden yola çıkarak bu çalışmada 60 - 94 yaş arası yaşlı yetişkinlerin SFT kullanılarak VKİ değerlerinin yaş gruplarında ve cinsiyete göre ve elde edilen SFT sonuçlarının standart norm değerleri ile karşılaştırılarak literatürdeki boşluğun doldurulması amaçlanmaktadır.

\section{YÖNTEM}

Araştırma Grubu: Araştırmaya yaşları 60-94 arasında olan 151 normal kilolu (71 kadın ve 80 erkek) ve 122 fazla kilolu (70 kadın ve 52 erkek) olmak üzere toplam 273 yaşlı yetişkin katılııştır. Katılımcıların tamamı Almanya Eberbach kenti TV Eberbach e.V. Sağlık Sporları Bölümünde tıbbi tedavinin desteklenmesi amacı ile sadece doktor reçetesi ile, engelli ya da engellilik riski taşıyan bireylerin kuvvet, dayanıklılık, beceri ve hareketliliğini gelişsirmek, ağrılarını hafifletmek, vücut ağıllığını dengelemek için uygulanan Rehabilitasyon Sporları Fiziksel Aktivite Programına en fazla on hafta süreyle katılmış olan bireyler arasından seçilmiştir. Araştırma grubunun belirlenmesinde kas ve kemik sistemini etkileyen ilaç kullanmak, kronik iltihaplanması olmak, felç geçirmiş olmak ve bağımsız şekilde hareket edemeyecek derecede fiziksel, ruhsal, duyusal ya da zihinsel rahatsızlığı olmak dışlanma kriteri olarak belirlenmiştir. Katılımcılar doktor reçetesi ile programa katıldıklarından dolayı fiziksel aktivite düzeyleri hakkında bir bilgi toplanmamıştır. Düzenlenen reçeteden katılımcıların spor geçmişlerinin olmadığı ve / ya da egzersizleri kendi başlarına yapacak yeterlilikte olmadıkları belirtilmiştir. Katılımcıların belirlenmesindeki kriterler daha önceden yapılan çalışmalar ile tutarlılık göstermektedir (Aksay, 2021; Baumgartner ve diğ., 2007; DOSB, 2016; Mahar ve Rowe, 2008; Morrow ve diğ., 2011; Rikli ve Jones, 2013b; Rikli ve Jones, 1999a). 
Yaşlı Yetişkinlerde Fonksiyonel Uygunluk: 60 - 94 Yaş Arası Normal ve Fazla Kilolu Yaşlı Yetişkinlerin

Fonksiyonel Uygunluklarının Karşılaştırılması

Functional Fitness for Older Adults: Comparison of Functional Fitness of Normal Weight and Overweight

Older Adults between the ages of 60-94

Veri Toplama Araçları: Araştırmada fonksiyonel uygunluğun belirlenmesi için SFT kullanılmıştır. Fizyoterapist Dr. Roberta Rikli ve Dr. Jessie Jones tarafından yaşlanmanın beraberinde getirdiği güçlükler göz önüne alınarak geliştirilen SFT (Rikli ve Jones, 1999a; Rikli ve Jones, 1999b; Jones ve Rikli, 2002a) tıbbi muayene gerekmeden 60-94 yaş arası bireylerin sınırlı bir alan içinde ya da evde yardım almadan uygulanabilecekleri şekilde düzenlenmiştir ve kısa sürede yapılabilmektedir. SFT bacak kuvveti, kol kuvveti, aerobik dayanıklılık, kalça esnekliği, omuz esnekliği, çeviklik/denge (Rikli ve Jones, 1999a; Rikli ve Jones; 1999b; Rikli ve Jones 2013a; Rikli ve Jones; 2013b,) ölçümlerine yönelik altı farklı test parametresinden oluşmaktadır.

Otur-kalk testi: Bacak kuvvetini belirlemek için uygulanmıştır. Katılımcı kollarını göğüs üzerinde çapraz bir şekilde tutarak sandalyeye oturur şekilde testte başlamış, komut ile beraber 30 saniye dizleri düz olacak şekilde ayağa kalkıp tekrar oturmuştur. Katılımcıya tek deneme verilmiş ve her ayağa kalkışı tekrar olarak kaydedilmiştir.

Kol bükme testi: Kol kuvvetini belirlemek için uygulanmıştır. Katılımcı dominant olan vücut kısmı sandalyenin dış kenarına gelecek şekilde sandalyeye oturmuş ve el halterini kol gergin şekilde dominant el ile tutmuştur. Komut ile beraber 30 saniye boyunca ön kol bükülerek halteri omuza doğru kaldırılıp ve tekrar aşağı doğru indirmiştir. Halterin kol gergin şekilde aşağıya ulaştığı anda tekrar sayıları doğru kabul edilmiş ve kaydedilmiştir. Kullanılan orijinal ağırlıklar erkeklerde 3,6 kg, kadınlarda 2,3 kg’dır. Ancak Almanya/Avrupa standartları düşünüldüğünde bu ağırlıkların temin edilmesi çok pratik ve kolay değildir. Bu nedenle kadınlar için 2,5 kg, erkekler için 3,5 kg’lık ağırlıklar kullanılmıştır.

Diz çekme testi: Aerobik dayanıklılığı belirlemek için uygulanmıştır. Katılımcının diz kapağının ortası ile ön kalça kemiğinin ortasına denk gelen yükseklik renkli bir bant ile duvara işaretlenmiştir. Katılımcı komut ile beraber iki dakika boyunca yerinde sayarak dizlerini işaretlenen yüksekliğe kaldırmıştır. Sağ diz istenilen yüksekliğe her ulaştığında, sayma makinesi ile sayım gerçekleştirilmiş ve tek deneme verilmiştir.

Otur-yürü testi: Çeviklik ve dinamik dengeyi belirlemek için uygulanmıştır. Sandalyenin ön ucundan 2,45 m uzaklığa bir huni yerleştirilmiştir. Katılımcı teste sandalyenin orta kısmında vücudu dik bir şekilde oturarak başlamış ve komut ile beraber ayağa kalkıp, huninin etrafından mümkün olan en yüksek hızda bir tur dönerek tekrar sandalyenin üzerine oturmuştur. Süre, çıkış sinyali ile başlamış, tekrar sandalyeye oturulunca durdurulmuştur. Her katılımcıya iki hak verilmiş ve en iyi süre saniye olarak değerlendirmeye alınmıştır.

Otur-uzan testi: Alt vücut/kalça esnekliğini belirlemek için uygulanmıştır. Katılımcı kalçaları sandalyenin ön kenarına bir bacak bükülü pozisyonda ayak tabanı yere gelecek şekilde, diğer bacak ise mümkün olduğu kadar gergin bir şekilde öne doğru uzatır pozisyonda oturmuştur. Gergin olan bacağın topuğunun yerde ve ayak ile kaval kemiği $90^{\circ}$ açıda olmasına dikkat edilmiştir. Katılımcı kollar gergin şekilde ellerini üst üste koyarak öne doğru ayak parmak uçlarına doğru eğilmiş ve ulaşılan en uç noktada pozisyon iki saniye korunmuştur. Ölçüm orta parmak ile ayak parmak ucundan alınmıştır. Orta parmak ayak uçlarına dokunursa " 0 ” olarak, ulaşmasa eksi (-) cm, geçerse artı (+) cm olarak kaydedilmiştir. Eksiden (-) sıfıra (0) doğru olan değer olumlu gelişme olarak sayılmıştır.

Sırt kaşıma testi: Omuz esnekliğini belirlemek için uygulanmıştır. Katılımcı ayakta durarak tercih ettiği elini omuz arkasından, sırt üzerinde kalçaya doğru uzatmıştır. Bu pozisyonda parmaklar gergin, dirsek yukarıyı, avuç içi gövdeyi gösterir şekildedir. Katılımcı avuç içleri dışarıyı gösterecek şekilde diğer el ile bel üzerinden üstteki ele ulaşmaya çalışmıştır. Burada iki orta parmağın birbirine değdirilmesi beklenmiş ve ölçüm iki orta parmağın uç kısımlarından alınmıştır. Parmak uçları birbirine dokunursa sıfır (0), ulaşmasa eksi (-) cm, geçerse artı (+) cm olarak kaydedilmiştir. 
Eksiden (-) sıfira (0) doğru olan değer olumlu gelişme olarak değerlendirilmiştir. İki test tekrarı yapılarak en iyi sonuç cm olarak kaydedilmiştir.

Alıntı yapılan testin metrik özellikleri Rikli ve Jones'un (1999a; 2013a) araştırmasında ayrıntılı olarak tanımlanmıştır.

İşlem Yolu: Çalışma öncesi Almanya Eberbach kentinde bulunan TV Eberbach e.V. Rehabilitasyon Spor Kulübü ile iletişime geçilmiş, kulüp yönetiminin önerileri doğrultusunda araştırmanın içeriği ve katılım şartlarının yer aldığı bilgilendirme broşürü hazırlanmıştır. Hazırlanan broşür Rehabilitasyon Sporu Programına katılan yaşlı yetişkinlere dağıtılmış ve yaşları 60-94 arasında olan 307 bireyden geri dönüt alınmıştır. Ancak 34 birey şartların uymaması, hastalanma, sakatlanma vb. sebeplerden dolayı kendi istekleriyle araştırmaya katılmayarak 273 kişilik araştırma grubu belirlenmiştir. Araştırmaya katılmayı kabul eden 273 kişi düzenli olarak katıldıkları program saatlerinde 6-8 kişilik gruplar halinde testin yapılacağı salona alınmıştır. Test öncesi gruptaki katılımcıların tamamının vücut ağırlık ve boy uzunluk ölçümleri VKİ değerlerini otomatik olarak hesaplayan Seca 769 dijital ağırlık/boy ölçme aleti ile yapılmıştır. DSÖ'nün belirlediği referans aralıklarına göre VKİ değerleri $25 \mathrm{~kg} / \mathrm{m} 2$ altında olan 151 birey normal kilolu (NK) ve 25 $\mathrm{kg} / \mathrm{m} 2$ üzeri olan 122 birey fazla kilolu (FK) grubunu oluşturmuştur. Test parametreleri araştırmacı tarafindan uygulamalı olarak gösterilmiş ve orijinal çalışmada olduğu gibi otur-kalk, kol bükme, diz çekme, otur-uzan, otur-yürü, sırt kaşıma sıralaması ile yapılmıştır. Orijinal çalışmaya uygun olarak teste katılan her katılımıının tüm test parametrelerini arka arkaya yapması istenmiş ve test parametreleri arasında istenilmesi durumunda 30-90 saniyelik dinlenme arası verilmiştir. Her katılımcı test parametrelerinin tamamın 7-13 dakika arasında tamamlamıştır. Hafta içi günlük olarak 25-30 bireyin ölçüm değerleri alınmış ve araştırmaya katılan 273 bireyin ölçümleri iki haftada tamamlanmıştır.

Verilerin toplanması "Federal Veri Koruma Yasası" (BDSG) hükümlerine uygun olarak gerçekleştirilmiştir. İlgili Federasyon ve Almanya TV Eberbach e.V. Sağlık Sporları Bölümünden gerekli onay alınmıştır (TVE/GS 2019-021). Çalışmaya katılım gönüllülük esasına dayanmakta olup, Helsinki Bildirgesine uygun olarak katılımcılar çalışmanın amaçları, içeriği, verilerin korunması hakkında bilgilendirilmiş ve katılımcılardan imzalı onam formu alınmıştır.

Verilerin Analizi: Verilerin analizlerinde (IBM SPSS 26-for Mac) araştırma grubunun özeliklerinin tanımlanması için betimsel istatistik analizi (ortalama, standart sapma, frekans ve yüzde) yapılmıştır. Verilerin normal dağılıma uygun olup olmadığını belirlemek için Kolmogorov-Smirnov, normal dağılımın diğer varsayımları olan çarpıklık - basıklık (skewness-kurtosis) değerleri ve histogram grafiğinden yararlanılmıştır. Çarpıklık - basıklık değerleri \pm 2 (George ve Mallery, 2010) aralığında olduğu için verilerin dağılımı normal olarak kabul edilmiştir. Bağımsız iki grup karşılaştırmasında t-testi (Independent sample t-test) bağımsız ikiden fazla grubun karşılaştırılmasında tek yönlü varyans analizi ve farkın kaynağının belirlenmesi için post hoc testlerinden Bonferroni testi kullanılmışır. Analizler sonucu istatistiksel olarak anlamlı farkın bulunduğu durumlarda farkın etki büyüklüğünü anlamak için Cohen's d ve kısmı eta kare hesaplanmıştır. Cohen'e göre (1988) d değerinin 0,2'den küçük olması durumunda etki büyüklüğünün zayıf, 0,5 olması durumunda orta ve 0,8 'den büyük olması durumunda ise kuvvetli olarak tanımlanabileceğini belirtilmektedir. Eta kare değeri 0,01 ise düşük, 0,06 değeri orta ve 0,14 ve üzeri ise yüksek etki büyüklüğü olarak kabul edilmektedir (Kilmen, 2015). Elde edilen değerlerin yorumlanmasında 0.05 anlamlılık düzeyi ölçüt olarak kullanılmışıtır.

\section{BULGULAR}

Katılımcıların yaş, boy, kilo ve VKİ ortalama ve standart sapma değerleri Tablo 1'de gösterilmiştir. 
Yaşlı Yetişkinlerde Fonksiyonel Uygunluk: 60 - 94 Yaş Arası Normal ve Fazla Kilolu Yaşlı Yetişkinlerin

Fonksiyonel Uygunluklarının Karşılaştırılması

Functional Fitness for Older Adults: Comparison of Functional Fitness of Normal Weight and Overweight

Older Adults between the ages of 60-94

Tablo 1

Katılımcıların Tanımlayıcı Özellikleri

\begin{tabular}{lllccccccc}
\hline & \multicolumn{4}{c}{ Normal Kilolu } & \multicolumn{3}{c}{ Fazla Kilolu } \\
\hline Değiş̧kenler & Cinsiyet & $\mathbf{n}$ & Min. & Maks. & $\overline{\mathbf{X}} \pm$ Ss & $\mathbf{n}$ & Min & Maks & $\overline{\mathbf{X}} \pm$ Ss \\
\hline \multirow{2}{*}{ Yaş } & Kadın & 71 & 60 & 93 & $72,3 \pm 10,41$ & 70 & 60 & 89 & $70,7 \pm 7,92$ \\
\cline { 2 - 10 } & Erkek & 80 & 60 & 91 & $72,5 \pm 9,15$ & 52 & 60 & 91 & $73,2 \pm 9,51$ \\
\hline \multirow{2}{*}{ Boy $(\mathrm{cm})$} & Kadın & 71 & 151 & 190 & $166,0 \pm 6,61$ & 70 & 153 & 187 & $164,5 \pm 7,74$ \\
\cline { 2 - 10 } & Erkek & 80 & 159 & 189 & $172,2 \pm 7,50$ & 52 & 157 & 193 & $169,7 \pm 7,91$ \\
\hline \multirow{2}{*}{ Ağırlık $(\mathrm{kg})$} & Kadın & 71 & 55 & 85 & $64,6 \pm 7,12$ & 70 & 60 & 106 & $78,2 \pm 9,72$ \\
\cline { 2 - 10 } & Erkek & 80 & 58 & 86 & $67,2 \pm 8,02$ & 52 & 66 & 94 & $78,9 \pm 6,90$ \\
\hline \multirow{2}{*}{ VKİ $\left(\mathrm{kg} / \mathrm{m}^{2}\right)$} & Kadın & 71 & 21,16 & 24,92 & $23,6 \pm, 76$ & 70 & 25,10 & 40,16 & $29,10 \pm 3,72$ \\
\cline { 2 - 9 } & Erkek & 80 & 21 & 24,73 & $22,9 \pm 1,21$ & 52 & 25,04 & 32,86 & $27,4 \pm 2,57$ \\
\hline
\end{tabular}

VKİ: Vücut Kütle İndeksi ( $\left.\mathrm{kg} / \mathrm{m}^{2}\right)$, Min: Minimum, Maks: Maksimum, Ss: Standart sapma.

Tablo 1 incelendiğinde FK grubundaki kadınların yaş ve boy ortalamasının NK grubundaki kadınların yaş ve boy ortalamasından daha düşük, FK grubundaki erkeklerin yaş ortalamasının NK grubundaki erkeklerin yaş ortalamasından daha yüksek ve boy ortalamasının daha düşük olduğu görülmektedir. NK grubundaki VKİ değerlerinin kadınlarda

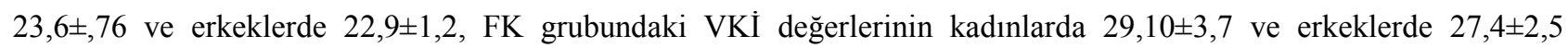
aralığında olduğu görülmektedir.

Yapılan istatistiksel analiz sonuçlarına göre NK grubundaki bireyler tüm SFT değişkenlerinde FK grubundaki bireylere göre anlamlı derecede yüksek performans değerleri sergilemişlerdir $(p<0,05)$. Elde edilen verilerden otur-kalk (d:0,86), diz çekme (d:0,89) otur yürü $(\mathrm{d}: 0,81)$, otur-uzan testlerinde $(\mathrm{d}: 0,55)$ bu farkın kuvvetli etki büyüklüğünde, kol bükme (d: 0,49) ve sırt kaşıma (d:0,40) testlerinde ise orta etki büyüklüğünde olduğu saptanmıştır (Tablo 2).

Tablo 2

Normal Kilolu ve Fazla Kilolu Gruplarına Göre SFT Sonuçları

\begin{tabular}{|c|c|c|c|c|c|c|c|}
\hline Değișkenler & Grup & $\mathbf{n}$ & $\overline{\mathbf{X}} \pm \mathrm{Ss}$ & $\mathbf{t}$ & df & $\mathbf{p}$ & Cohen's d \\
\hline \multirow{2}{*}{$\begin{array}{l}\text { Otur-kalk (30 } \\
\text { sn/tekrar) }\end{array}$} & NK & 151 & $13,76 \pm 3,95$ & \multirow{2}{*}{9,57} & \multirow{2}{*}{271} & \multirow{2}{*}{0,01} & \multirow{2}{*}{0,86} \\
\hline & FK & 122 & $9,70 \pm 2,81$ & & & & \\
\hline \multirow{2}{*}{$\begin{array}{l}\text { Kol bükme (30 } \\
\text { sn/tekrar) }\end{array}$} & NK & 151 & $14,35 \pm 2,99$ & \multirow{2}{*}{5,47} & \multirow{2}{*}{271} & \multirow{2}{*}{0,01} & \multirow{2}{*}{0,49} \\
\hline & FK & 122 & $12,53 \pm 2,36$ & & & & \\
\hline \multirow{2}{*}{$\begin{array}{l}\text { Diz çekme (2 } \\
\text { dk/tekrar) }\end{array}$} & NK & 151 & $81,42 \pm 18,70$ & \multirow{2}{*}{9,68} & \multirow{2}{*}{271} & \multirow{2}{*}{0,01} & \multirow{2}{*}{0,89} \\
\hline & FK & 122 & $61,73 \pm 13,81$ & & & & \\
\hline \multirow{2}{*}{$\begin{array}{l}\text { Otur-yürü }(2,4 \\
\mathrm{m} / \mathrm{sn})\end{array}$} & NK & 151 & $5,57 \pm 1,44$ & \multirow{2}{*}{$-9,00$} & \multirow{2}{*}{271} & \multirow{2}{*}{0,01} & \multirow{2}{*}{0,81} \\
\hline & FK & 122 & $7,14 \pm 1,43$ & & & & \\
\hline \multirow{2}{*}{ Otur-uzan (cm) } & NK & 151 & $, 53 \pm 6,18$ & \multirow{2}{*}{6,15} & \multirow{2}{*}{271} & \multirow{2}{*}{0,01} & \multirow{2}{*}{0,55} \\
\hline & FK & 122 & $-3,80 \pm 5,21$ & & & & \\
\hline \multirow{2}{*}{ Sırt kaşıma (cm) } & NK & 151 & $-8,15 \pm 6,62$ & \multirow{2}{*}{4,49} & \multirow{2}{*}{271} & \multirow{2}{*}{0,01} & \multirow{2}{*}{0,40} \\
\hline & FK & 122 & $-11,51 \pm 5,46$ & & & & \\
\hline
\end{tabular}

NK: Normal kilolu, FK: Fazla kilolu, Ss: Standart sapma, SFT: Senior Fitness Test

VKİ ve cinsiyete göre yaş sınıflaması karşılaştırmaları Tablo 3'te gösterilmiştir. İstatiksel bağlamda bir tutarlığın oluşturulması için orijinal çalışmada olduğu gibi yedi yaş grubu belirlenmiştir (60-64, 65-69, 70-74, 75-79, 80-84, 85-89, 90+). Elde edilen veriler normal kilolu ve fazla kilolu gruplar arasında yaş sınıflamasına göre otur-kalk, kol bükme, diz çekme, otur-yürü, otur-uzan ve sırt kaşıma testlerinin tamamında kadın ve erkeklerde istatiksel olarak anlamlı bir farklılığın olduğu $(\mathrm{p}<0,05)$ ve hesaplanan etki büyüklüğü değerleri, gruplar arası farklılıkların kuvvetli düzeyde olduğunu 
göstermektedir. Kuvvet, dayanıklılık, beceri ve esneklik özelliklerinde yaş ilerledikçe beklenildiği üzere performansın düştüğü ve performans kaybının özellikle 70 yaşından sonra başladığı görülmektedir.

Normal kilolu erkeklerin otur-kalk 60-64 yaş değerleri diğer tüm yaş gruplarına, 65-69 yaş değerleri 70-74 üstü, 7074 yaş değerleri 75-79 üstü, 75-79 yaş değerleri 80-84 üstü, 80-84 yaş değerleri 85-89 üstü gruplara göre anlamlı biçimde daha yüksektir. Kol bükme 60-64 yaş değerleri diğer tüm yaş gruplarına, 65-69 yaş değerleri 70-74 üstü, 70-74 yaş değerleri 85-89 üstü, 75-79 yaş değerleri 85-89 üstü, 80-84 yaş değerleri 85-89 üstü gruplara göre anlamlı biçimde daha yüksektir. Diz çekme 60-64 yaş değerleri 70-74 üstü, 65-69 yaş değerleri 70-74 üstü, 70-74 yaş değerleri 80-84 üstü, 7579 yaş değerleri 80-84 üstü, 80-84 yaş değerleri 85-89 üstü gruplara göre anlamlı biçimde daha yüksektir. Otur yürü 6064 yaş değerleri diğer tüm yaş gruplarına, 65-69 yaş değerleri 80-84 üstü, 70-74 yaş değerleri 80-84 üstü, 75-79 yaş değerleri 80-84 üstü, 80-84 ve 85-89 değerleri, 90-94 yaş grubuna göre anlamlı biçimde daha düşüktür.

Normal kilolu kadınların otur-kalk 60-64 yaş değerleri 70-74 üstü, 65-69 yaş değerleri 70-74 üstü, 70-74 yaş değerleri 90-94 grubuna göre, 75-79 yaş değerleri 90-94 yaş grubuna göre anlamlı biçimde daha yüksektir. Kol bükme 60-64 yaş değerleri 70-74 üstü, 65-69 yaş değerleri 75-79 üstü, 70-74 yaş değerleri 85-89 üstü, 75-79 yaş değerleri 85-89 üstü, 8084 yaş değerleri 90-94 yaş grubuna göre anlamlı biçimde daha yüksektir. Diz çekme 60-64 yaş değerleri 70-74 üstü gruplara göre, 65-69 yaş değerleri 75-79 üstü, 70-74 yaş değerleri 80-84 üstü, 75-79 yaş değerleri 85-89 üstü, 80-84 yaş değerleri 90-94 yaş grubuna göre anlamlı biçimde daha yüksektir. Otur yürü 60-64 yaş değerleri 75-79 ve üzeri, 65-69 yaş değerleri 75-79 üstü, 70-74 yaş değerleri 75-79 üstü gruplara göre anlamlı biçimde daha düşüktür.

Fazla kilolu erkeklerin otur-kalk 60-64 yaş değerleri 70-74 üstü, 65-69 yaş değerleri 75-79 üstü, 70-74 yaş değerleri 85-89 üstü, 75-79 yaş değerleri 90-94 yaş grubuna göre anlamlı biçimde daha yüksektir. Kol bükme 60-64 yaş değerleri 70-74 üstü, 65-69 yaş değerleri 80-84 üstü, 70-74 yaş değerleri 85-89 üstü, 75-79 yaş değerleri 85-89 üstü gruplara göre anlamlı biçimde daha yüksektir. Diz çekme 60-64 yaş değerleri 70-74 üstü, 65-69 yaş değerleri 80-84 üstü, 70-74 yaş değerleri 85-89 üstü, 75-79 yaş değerleri 85-89 üstü gruplara göre anlamlı biçimde daha yüksektir. Otur yürü 60-64 yaş diğer tüm yaş gruplarına göre, 65-69 yaş değerleri 80-84 üstü, 70-74 yaş değerleri 85-89 üstü, 75-79 yaş değerleri 85-89 üstü, 80-84 yaş değerleri 85-89 üstü gruplara göre anlamlı biçimde daha düşüktür.

Fazla kilolu kadınların otur-kalk 60-64 yaş değerleri 70-74 üstü, 65-69 yaş değerleri 75-79 üstü, 70-74 yaş değerleri 80-84 üstü gruba göre anlamlı biçimde yüksektir. Kol bükme 60-64 yaş diğer tüm yaş gruplarına göre, 65-69 yaş değerleri 80-84 üstü, 70-74 yaş değerleri 80-84 üstü, 75-79 yaş değerleri 85-89 yaş üstü, 80-84 yaş değerleri 90-94 grubuna göre anlamlı biçimde yüksektir. Diz çekme 60-64 yaş değerleri 75-79 üstü, 65-69 yaş değerleri 75-79 üstü, 70-74 yaş değerleri 85-89 yaş grubuna göre anlamlı biçimde daha yüksektir. Otur yürü 60-64 yaş 75-79 üstü, 65-69 yaş değerleri 75-79 üstü, 70-74 yaş değerleri 80-84 üstü, 75-79 yaş değerleri 80-84 üstü, 80-84 yaş değerleri 85-89 yaş grubuna göre anlamlı biçimde düşüktür. 
Tablo 3

Erkek Katılımcıların Yaş Gruplarına İlişkin SFT Sonuçları

Normal Kilolu

Fazla Kilolu

\begin{tabular}{|c|c|c|c|c|c|c|c|c|c|c|c|}
\hline Değişkenler & Yaş/Yıl & $\mathbf{n}$ & $\overline{\mathbf{X}} \pm \mathbf{S s}$ & $\mathbf{F}^{*}$ & $\begin{array}{c}\text { Kismi } \\
\text { etakare }\end{array}$ & Fark & $\mathbf{n}$ & $\overline{\mathbf{X}} \pm \mathbf{S s}$ & $\mathbf{F}^{*}$ & $\begin{array}{c}\text { Kismi } \\
\text { etakare }\end{array}$ & Fark \\
\hline \multirow{7}{*}{$\begin{array}{l}\text { Otur-kalk (30 } \\
\text { sn/tekrar) }\end{array}$} & $60-64^{A}$ & 20 & $19,3 \pm, 86$ & \multirow{7}{*}{24,74} & \multirow{7}{*}{0,93} & $\mathrm{~A}>\mathrm{B}, \mathrm{C}, \mathrm{D}, \mathrm{E}, \mathrm{F}, \mathrm{G}$ & 9 & $14,1 \pm 1,72$ & \multirow{7}{*}{157,96} & \multirow{7}{*}{0,72} & $\mathrm{~A}>\mathrm{C}, \mathrm{D}, \mathrm{E}, \mathrm{F}, \mathrm{G}$ \\
\hline & $65-69^{\mathrm{B}}$ & 16 & $18,1 \pm 1,13$ & & & $\mathrm{~B}>\mathrm{C}, \mathrm{D}, \mathrm{E}, \mathrm{F}, \mathrm{G}$ & 10 & $13,4 \pm 1,41$ & & & $\mathrm{~B}>\mathrm{D}, \mathrm{E}, \mathrm{F}, \mathrm{G}$ \\
\hline & $70-74^{\mathrm{C}}$ & 10 & $16,5 \pm 1,32$ & & & $\mathrm{C}>\mathrm{D}, \mathrm{E}, \mathrm{F}, \mathrm{G}$ & 9 & $11,2 \pm 1,31$ & & & $\mathrm{C}>\mathrm{F}, \mathrm{G}$ \\
\hline & $75-79^{\mathrm{D}}$ & 9 & $13,8 \pm, 60$ & & & $\mathrm{D}>\mathrm{E}, \mathrm{F}, \mathrm{G}$ & 9 & $9,8 \pm 1,52$ & & & $\mathrm{E}>\mathrm{G}$ \\
\hline & $80-84^{\mathrm{E}}$ & 12 & $12,0 \pm 1,22$ & & & $\mathrm{E}>\mathrm{F}, \mathrm{G}$ & 5 & $8,6 \pm 1,12$ & & & \\
\hline & $85-89^{\mathrm{F}}$ & 10 & $9,9 \pm 1,11$ & & & & 6 & $7,8 \pm 1,4$ & & & \\
\hline & $>90^{\mathrm{G}}$ & 3 & $8,3 \pm, 52$ & & & & 4 & $6,5 \pm 1,24$ & & & \\
\hline \multirow{7}{*}{$\begin{array}{l}\text { Kol bükme } \\
\text { (30 sn/tekrar) }\end{array}$} & $60-64^{\mathrm{A}}$ & 20 & $18,9 \pm 1,01$ & \multirow{7}{*}{23,62} & \multirow{7}{*}{0,87} & $\mathrm{~A}>\mathrm{B}, \mathrm{C}, \mathrm{D}, \mathrm{E}, \mathrm{F}, \mathrm{G}$ & 9 & $16,3 \pm 2,22$ & \multirow{7}{*}{27,62} & \multirow{7}{*}{0,81} & $\mathrm{~A}>\mathrm{B}, \mathrm{C}, \mathrm{D}, \mathrm{E}, \mathrm{F}, \mathrm{G}$ \\
\hline & $65-69^{\mathrm{B}}$ & 16 & $17,1 \pm, 75$ & & & $\mathrm{~B}>\mathrm{C}, \mathrm{D}, \mathrm{E}, \mathrm{F}, \mathrm{G}$ & 10 & $14,5 \pm, 70$ & & & $\mathrm{~B}>\mathrm{E}, \mathrm{F}, \mathrm{G}$ \\
\hline & $70-74^{\mathrm{C}}$ & 10 & $15,4 \pm, 96$ & & & $\mathrm{C}>\mathrm{F}, \mathrm{G}$ & 9 & $13,6 \pm 1,11$ & & & $\mathrm{C}>\mathrm{F}, \mathrm{G}$ \\
\hline & $75-79^{\mathrm{D}}$ & 9 & $15,1 \pm, 60$ & & & $\mathrm{D}>\mathrm{F}, \mathrm{G}$ & 9 & $13,2 \pm 1,54$ & & & $\mathrm{D}>\mathrm{F}, \mathrm{G}$ \\
\hline & $80-84^{\mathrm{E}}$ & 12 & $14,2 \pm 1,22$ & & & $\mathrm{E}>\mathrm{F}, \mathrm{G}$ & 5 & $11,4 \pm 1,53$ & & & \\
\hline & $85-89^{\mathrm{F}}$ & 10 & $11,9 \pm 1,12$ & & & & 6 & $10,3 \pm, 81$ & & & \\
\hline & $>90^{\mathrm{G}}$ & 3 & $10,3 \pm 1,13$ & & & & 4 & $9,2 \pm, 95$ & & & \\
\hline \multirow{7}{*}{$\begin{array}{l}\text { Diz çekme (2 } \\
\text { dk/tekrar) }\end{array}$} & $60-64^{\mathrm{A}}$ & 20 & $109,6 \pm, 5,41$ & \multirow{7}{*}{19,29} & \multirow{7}{*}{0,90} & $\mathrm{~A}>\mathrm{C}, \mathrm{D}, \mathrm{E}, \mathrm{F}, \mathrm{G}$ & 9 & $83,8 \pm 7,82$ & \multirow{7}{*}{82,85} & \multirow{7}{*}{0,86} & $\mathrm{~A}>\mathrm{C}, \mathrm{D}, \mathrm{F}, \mathrm{G}$ \\
\hline & $65-69^{\mathrm{B}}$ & 16 & $103,1 \pm, 3,32$ & & & $\mathrm{~B}>\mathrm{C}, \mathrm{D}, \mathrm{E}, \mathrm{F}, \mathrm{G}$ & 10 & $74,63 \pm, 93$ & & & $\mathrm{~B}>\mathrm{E}, \mathrm{F}, \mathrm{G}$ \\
\hline & $70-74^{\mathrm{C}}$ & 10 & $93,5 \pm, 13,62$ & & & $\mathrm{C}>\mathrm{E}, \mathrm{F}, \mathrm{G}$ & 9 & $72,4 \pm 6,32$ & & & $\mathrm{C}>\mathrm{F}, \mathrm{G}$ \\
\hline & $75-79^{\mathrm{D}}$ & 9 & $85,2 \pm, 9,12$ & & & $\mathrm{D}>\mathrm{E}, \mathrm{F}, \mathrm{G}$ & 9 & $68,3 \pm 9,10$ & & & \\
\hline & $80-84^{\mathrm{E}}$ & 12 & $73,8 \pm, 4,61$ & & & E>F.G & 5 & $62,2 \pm 2,20$ & & & \\
\hline & $85-89^{\mathrm{F}}$ & 10 & $58,5 \pm, 2,02$ & & & & 6 & $56,0 \pm 4,55$ & & & \\
\hline & $>90^{\mathrm{G}}$ & 3 & $52,3 \pm, 3,01$ & & & & 4 & $51,2 \pm 4,92$ & & & \\
\hline \multirow{7}{*}{$\begin{array}{l}\text { Otur-yürü } \\
(2,4 \mathrm{~m} / \mathrm{sn})\end{array}$} & $60-64^{\mathrm{A}}$ & 20 & $5,2 \pm, 87$ & \multirow{7}{*}{14,93} & \multirow{7}{*}{0,90} & $\mathrm{~A}<\mathrm{B}, \mathrm{C}, \mathrm{D}, \mathrm{E}, \mathrm{F}, \mathrm{G}$ & 9 & $5,0 \pm, 50$ & \multirow{7}{*}{46,24} & \multirow{7}{*}{0,62} & $\mathrm{~A}<\mathrm{B}, \mathrm{C}, \mathrm{D}, \mathrm{E}, \mathrm{F}, \mathrm{G}$ \\
\hline & $65-69^{\mathrm{B}}$ & 16 & $5,1 \pm, 53$ & & & $\mathrm{~A}<\mathrm{E}, \mathrm{F}, \mathrm{G}$ & 10 & $6,3 \pm, 33$ & & & $\mathrm{~B}<\mathrm{E}, \mathrm{F}, \mathrm{G}$ \\
\hline & $70-74^{\mathrm{C}}$ & 10 & $4,8 \pm, 00$ & & & $\mathrm{C}<\mathrm{E}, \mathrm{F}, \mathrm{G}$ & 9 & $6,5 \pm, 43$ & & & $\mathrm{C}<\mathrm{F}, \mathrm{G}$ \\
\hline & $75-79^{\mathrm{D}}$ & 9 & $6,6 \pm, 40$ & & & $\mathrm{D}<\mathrm{E}, \mathrm{F}, \mathrm{G}$ & 9 & $6,7 \pm, 63$ & & & $\mathrm{D}<\mathrm{F}, \mathrm{G}$ \\
\hline & $80-84^{\mathrm{E}}$ & 12 & $6,6 \pm, 37$ & & & $\mathrm{E}<\mathrm{G}$ & 5 & $7,2 \pm, 31$ & & & $\mathrm{~F}<\mathrm{F}, \mathrm{G}$ \\
\hline & $85-89^{\mathrm{F}}$ & 10 & $7,6 \pm 1,23$ & & & $\mathrm{~F}<\mathrm{G}$ & 6 & $9,0 \pm, 53$ & & & \\
\hline & $>90^{\mathrm{G}}$ & 3 & $8,7 \pm, 60$ & & & & 4 & $9,7 \pm, 68$ & & & \\
\hline
\end{tabular}

$* \mathrm{p}<0,05$, SFT: Senior Fitness Test 
Tablo 4

Kadın Katılımcıların Yaş Gruplarına İlişkin SFT Sonuçları

\begin{tabular}{|c|c|c|c|c|c|c|c|c|c|c|c|}
\hline \multirow[b]{2}{*}{ Değişkenler } & \multirow[b]{2}{*}{ Yaş/Yıl } & \multicolumn{5}{|c|}{ Normal Kilolu } & \multicolumn{5}{|c|}{ Fazla Kilolu } \\
\hline & & $\mathbf{n}$ & $\overline{\mathbf{X}} \pm \mathbf{S s}$ & $\mathbf{F}^{*}$ & $\begin{array}{c}\text { Kismi } \\
\text { etakare }\end{array}$ & Fark & $\mathbf{n}$ & $\overline{\mathbf{X}} \pm \mathbf{S s}$ & $\mathbf{F}^{*}$ & $\begin{array}{c}\text { Kismi } \\
\text { etakare }\end{array}$ & Fark \\
\hline \multirow{7}{*}{$\begin{array}{l}\text { Otur-kalk (30 } \\
\text { sn/tekrar) }\end{array}$} & $60-64^{\mathrm{A}}$ & 24 & $14,6 \pm 2,41$ & \multirow{7}{*}{64,96} & \multirow{7}{*}{0,77} & $\mathrm{~A}>\mathrm{C}, \mathrm{D}, \mathrm{E}, \mathrm{F}, \mathrm{G}$ & 16 & $10,6 \pm 1,32$ & 85,33 & \multirow{7}{*}{0,65} & $\mathrm{~A}>\mathrm{B}, \mathrm{C}, \mathrm{D}, \mathrm{F}, \mathrm{G}$ \\
\hline & $65-69^{B}$ & 12 & $13,7 \pm 1,22$ & & & $\mathrm{~B}>\mathrm{C}, \mathrm{D}, \mathrm{E}, \mathrm{F}, \mathrm{G}$ & 21 & $10,1 \pm 1,93$ & & & $\mathrm{~B}>\mathrm{D}, \mathrm{E}, \mathrm{F}, \mathrm{G}$ \\
\hline & $70-74^{\mathrm{C}}$ & 8 & $11,1 \pm, 83$ & & & $\mathrm{C}>\mathrm{G}$ & 13 & $8,6 \pm, 96$ & & & $\mathrm{C}>\mathrm{E}, \mathrm{F}, \mathrm{G}$ \\
\hline & $75-79^{\mathrm{D}}$ & 8 & $10,1 \pm 1,13$ & & & $\mathrm{C}>\mathrm{G}$ & 8 & $6,6 \pm 1,82$ & & & \\
\hline & $80-84^{\mathrm{E}}$ & 6 & $9,6 \pm 1,76$ & & & & 7 & $5,7 \pm, 48$ & & & \\
\hline & $85-89^{\mathrm{F}}$ & 5 & $8,21,31$ & & & & 5 & $5,4 \pm, 89$ & & & \\
\hline & $>90^{\mathrm{G}}$ & 8 & $7,1 \pm 1,22$ & & & & - & - & & & \\
\hline \multirow{7}{*}{$\begin{array}{l}\text { Kol bükme } \\
\text { (30 sn/tekrar) }\end{array}$} & $60-64^{\mathrm{A}}$ & 24 & $14,6 \pm, 13$ & \multirow{7}{*}{29,34} & \multirow{7}{*}{0,73} & $\mathrm{~A}>\mathrm{C}, \mathrm{D}, \mathrm{E}, \mathrm{F}, \mathrm{G}$ & 16 & $13,9 \pm 1,23$ & 17,58 & \multirow{7}{*}{0,70} & $\mathrm{~A}>\mathrm{B}, \mathrm{C}, \mathrm{D}, \mathrm{E}, \mathrm{F}$ \\
\hline & $65-69^{\mathrm{B}}$ & 12 & $14,1 \pm 1,13$ & & & $\mathrm{~B}>\mathrm{D}, \mathrm{E}, \mathrm{F}, \mathrm{G}$ & 21 & $12,4 \pm 1,26$ & & & $\mathrm{~B}>\mathrm{E}, \mathrm{F}, \mathrm{G}$ \\
\hline & $70-74^{\mathrm{C}}$ & 8 & $12,8 \pm 1,46$ & & & $\mathrm{C}>\mathrm{F}, \mathrm{G}$ & 13 & $12,1 \pm 1,07$ & & & $\mathrm{C}>\mathrm{E}, \mathrm{F}, \mathrm{G}$ \\
\hline & $75-79^{\mathrm{D}}$ & 8 & $12,1 \pm 1,12$ & & & $\mathrm{D}>\mathrm{F}, \mathrm{G}$ & 8 & $11,2 \pm 1,23$ & & & $\mathrm{D}>\mathrm{F}, \mathrm{G}$ \\
\hline & $80-84^{\mathrm{E}}$ & 6 & $11,3 \pm, 51$ & & & $E>G$ & 7 & $10,1 \pm 1,25$ & & & $E>G$ \\
\hline & $85-89^{\mathrm{F}}$ & 5 & $9,8 \pm, 83$ & & & & 5 & $7,2 \pm, 83$ & & & \\
\hline & $>90^{\mathrm{G}}$ & 8 & $8,1 \pm, 83$ & & & & - & - & & & \\
\hline \multirow{7}{*}{$\begin{array}{l}\text { Diz çekme (2 } \\
\text { dk/tekrar) }\end{array}$} & $60-64^{\mathrm{A}}$ & 24 & $82,7 \pm 6,52$ & \multirow{7}{*}{22,75} & \multirow{7}{*}{0,73} & $\mathrm{~A}>\mathrm{C}, \mathrm{D}, \mathrm{E}, \mathrm{F}, \mathrm{G}$ & 16 & $63,1 \pm 8,82$ & 73,77 & \multirow{7}{*}{0,86} & $\mathrm{~A}>\mathrm{D}, \mathrm{E}, \mathrm{F}, \mathrm{G}$ \\
\hline & $65-69^{\mathrm{B}}$ & 12 & $78,3 \pm 2,31$ & & & $\mathrm{~B}>\mathrm{D}, \mathrm{E}, \mathrm{F}, \mathrm{G}$ & 21 & $62,2 \pm 11,43$ & & & $\mathrm{~B}>\mathrm{D}, \mathrm{E}, \mathrm{F}, \mathrm{G}$ \\
\hline & $70-74^{\mathrm{C}}$ & 8 & $71,7 \pm 3,91$ & & & $\mathrm{C}>\mathrm{E}, \mathrm{F}, \mathrm{G}$ & 13 & $55,6 \pm 10,24$ & & & $\mathrm{C}>\mathrm{F}, \mathrm{G}$ \\
\hline & $75-79^{\mathrm{D}}$ & 8 & $67,6 \pm 3,33$ & & & $\mathrm{D}>\mathrm{F}, \mathrm{G}$ & 8 & $48,8 \pm 4,77$ & & & \\
\hline & $80-84^{\mathrm{E}}$ & 6 & $62,6 \pm 2,51$ & & & $E>G$ & 7 & $43,2 \pm 3,46$ & & & \\
\hline & $85-89^{\mathrm{F}}$ & 5 & $58,81,72$ & & & & 5 & $35,4 \pm 5,94$ & & & \\
\hline & $>90^{\mathrm{G}}$ & 8 & $51,5 \pm 3,62$ & & & & - & --- & & & \\
\hline \multirow{7}{*}{$\begin{array}{l}\text { Otur-yürü } \\
(2,4 \mathrm{~m} / \mathrm{sn})\end{array}$} & $60-64^{\mathrm{A}}$ & 24 & $5,2 \pm, 87$ & \multirow{7}{*}{14,93} & \multirow{7}{*}{0,90} & $\mathrm{~A}<\mathrm{D}, \mathrm{E}, \mathrm{F}, \mathrm{G}$ & 16 & $6,4 \pm, 59$ & 45,77 & \multirow{7}{*}{0,70} & $\mathrm{~A}<\mathrm{D}, \mathrm{E}, \mathrm{F}, \mathrm{G}$ \\
\hline & $65-69^{\mathrm{B}}$ & 12 & $5,1 \pm, 53$ & & & $\mathrm{~B}<\mathrm{D}, \mathrm{E}, \mathrm{F}, \mathrm{G}$ & 21 & $6,6 \pm, 70$ & & & $\mathrm{~B}<\mathrm{D}, \mathrm{E}, \mathrm{F}, \mathrm{G}$ \\
\hline & $70-74^{\mathrm{C}}$ & 8 & $4,8 \pm, 00$ & & & $\mathrm{C}<\mathrm{D}, \mathrm{E}, \mathrm{F}, \mathrm{G}$ & 13 & $7,3 \pm 1,25$ & & & $\mathrm{C}<\mathrm{E}, \mathrm{F}, \mathrm{G}$ \\
\hline & $75-79^{\mathrm{D}}$ & 8 & $6,6 \pm, 40$ & & & & 8 & $7,7 \pm, 36$ & & & $\mathrm{D}<\mathrm{E}, \mathrm{F}, \mathrm{G}$ \\
\hline & $80-84^{\mathrm{E}}$ & 6 & $6,6 \pm, 37$ & & & & 7 & $8,9 \pm 1,07$ & & & $\mathrm{E}<\mathrm{F}$ \\
\hline & $85-89^{\mathrm{F}}$ & 5 & $7,2 \pm 1,31$ & & & & 5 & $10,5,47$ & & & \\
\hline & $>90^{\mathrm{G}}$ & 8 & $7,6 \pm 1,22$ & & & & - & - & & & \\
\hline
\end{tabular}

$* \mathrm{p}<0,05$, SFT: Senior Fitness Test 
Tablo 5’te Rikli ve Jones'un (2012) belirlediği otur-kalk, kol bükme, diz çekme ve otur-yürü alt testlerinin ortalama standart norm değerleri görülmektedir. Otur uzan ve sırt kaşıma testleri için standart norm değeri belirlenmemiştir.

Tablo 5

Rikli ve Jones'a (2012 S.262) Göre Fonksiyonel Hareketlilik ve Fiziksel Bă̆ımsızlı̆̆ın Korunması Için Ulaşılması Gereken SFT Norm Değerleri

\begin{tabular}{lcccccccc}
\hline & & \multicolumn{7}{c}{ Yaş Grupları } \\
\cline { 3 - 8 } Değişkenler & Cinsiyet & $\mathbf{6 0 - 6 4}$ & $\mathbf{6 5 - 6 9}$ & $\mathbf{7 0 - 7 4}$ & $\mathbf{7 5 - 7 9}$ & $\mathbf{8 0 - 8 4}$ & $\mathbf{8 5 - 8 9}$ & $>\mathbf{9 0}$ \\
\hline \multirow{2}{*}{ Otur-kalk (30 sn) } & Kadın & 15 & 15 & 14 & 13 & 12 & 11 & 9 \\
& Erkek & 17 & 16 & 15 & 14 & 13 & 11 & 9 \\
Kol bükme (30 sn) & Kadın & 17 & 17 & 16 & 15 & 14 & 13 & 11 \\
& Erkek & 19 & 18 & 17 & 16 & 15 & 13 & 11 \\
Diz çekme (2 dk) & Kadın & 97 & 93 & 89 & 84 & 78 & 70 & 60 \\
\multirow{2}{*}{ Otur-yürü (2,4m/sn) } & Erkek & 106 & 101 & 95 & 88 & 80 & 71 & 60 \\
& Kadın & 5,0 & 5,3 & 5,6 & 6,6 & 6,0 & 7,1 & 8,0 \\
& Erkek & 4,8 & 5,1 & 5,5 & 5,9 & 6,4 & 7,1 & 8,0 \\
\hline
\end{tabular}

Normal kilolu kadınların otur-kalk, kol bükme, diz çekme ve otur-yürü değerleri standart norm değerlerinden

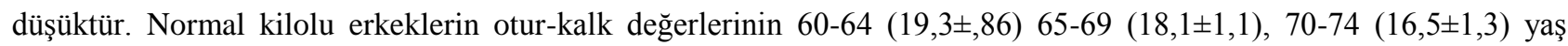
gruplarında, diz çekme değerlerinin 60-64 $(109,6 \pm, 5,4)$ ve 65-69 $(103,1 \pm, 3,3)$ yaş gruplarında standart norm değerlerine eşit, kol bükme ve otur-yürü değerlerinin tüm yaş gruplarında standart norm değerlerinden yüksek olduğu belirlenmiştir.

Fazla kilolu grubundaki kadın ve erkeklerin ölçüm değerlerinin testlerin tamamında standart norm değerlerinin daha düşük olduğu görülmektedir.

\section{TARTISMA}

Bu çalışmada 60 - 94 yaş arası yaşlı yetişkinlerin SFT kullanılarak VKİ değerlerinin yaş gruplarında ve cinsiyete göre ve elde edilen SFT sonuçlarının standart norm değerleri ile karşılaştırılması amaçlanmıştır. Elde edilen verilerin analizine dayanarak normal kiloluların ölçüm değerlerinin fazla kilolulara göre pozitif yönde daha yüksek ve gruplar arasında istatiksel olarak anlamlı farklılığın olduğu sonucuna ulaşılmıştır ( $<<0,05$; Tablo 2). Esneklik gerektiren testlerde kadınlar daha yüksek performans değerleri sergilerken, kuvvet, dayanıklılık, çeviklik/beceri gerektiren testlerde ise erkeklerin daha yüksek performans değerleri sergilediği ve yaş ilerledikçe beklenildiği üzere testlerin tamamında performansın düştüğü görülmektedir.

Bacak kuvvetinin değerlendirilmesi için otur-kalk ve kol kuvvetinin değerlendirmesi için kol bükme testleri uygulanmıştır. Bacak kuvvetinin yaşlı yetişkinlerde özellikle merdiven çıkmak, ayağa kalkmak, alışverişe gitmek, kol kuvvetinin ise ev işlerinin yapılması, su şişelerinin, alışveriş poşetlerinin ve bagajların taşınması vb. günlük aktivitelerde gerekli olduğu düşünülmektedir. 30 saniyelik otur-kalk testinde normal kiloluların fazla kilolulara göre yaş gruplarının tamamında daha yüksek değerlere ulaştıkları görülmektedir. Elde edilen veriler bu çalışmadaki 60-64 ve 65-69 yaş aralığındaki normal kilolu Almanya örnekleminin Amerika Birleşik Devletleri (ABD) örneklemi ile karşılaştırılabilir olduğunu gösterirken, diğer yaş gruplarında ise daha düşük değerlere ulaşılan sonuçlar ABD örnekleminden farklılık göstermektedir (Rikli ve Jones, 1999b). Kol kuvvetinin belirlenmesi için yapılan 30 saniyelik kol bükme testinde normal kilolu erkeklerin ölçüm değerlerinin ABD örneklemi ölçüm değerlerinden daha yüksek, kadınların ölçüm değerlerinin ise daha düşük olduğu görülmektedir (Rikli ve Jones, 1999b). Bunun nedeninin erkekler için kullanılan el halterinin daha 
hafif ve kadınlar için kullanılan el halterinin daha ağır olmasından kaynaklandığı düşünülmektedir. Genel olarak bacak kuvveti ve kol kuvvetini değerlendirmek için yapılan testlerde normal kiloluların fazla kilolulara göre daha düşük değerlere ulaştıkları ve gruplar arasında istatiksel olarak anlamlı farklılı̆ı̆ın olduğu sonucuna varılmıştır. Slovakya'da 59 normal kilolu ve 60 fazla kilolu yaşlı yetişkinle yapılan benzer bir çalışmada normal kiloluların ölçüm değerlerinin fazla kilolulara göre daha yüksek olduğu belirtilmiştir (Kostić ve diğ., 2011). Bu bağlamda düşünüldüğünde sonuçlar çalışmamızı destekler niteliktedir. Ancak Kostić ve diğerleri, (2011) gruplar arasında istatiksel bir farklılık olmadığını bildirmişlerdir. Bunun nedeninin Slovakya örnekleminin sadece 70-74 yaş grubu ile sınırlandırılmış olduğundan kaynaklandığg düşünülmektedir. Bununla birlikte belirtilen farklılıkların yaş grupları ve cinsiyetler arasında anlamlı olması benzer çalı̧̧maların sonuçlarını destekler niteliktedir (Aksay, 2021; Kostić ve diğ., 2011; Langhammer ve Stanghalle; 2018; Langhammer ve Stanghalle, 2011). Langhammer ve Stanghalle (2018) Norveç’te 60 yaş üstü 48 erkek ve 124 kadın ile yaptıkları benzer bir çalışmada bacak kuvvetinin ilerleyen yaş ile kol kuvvetine oranla daha fazla düştüğünü belirlemişlerdir. Bu sonuçlardan yola çıkarak 60 yaş üzeri yaşlı yetişkinlerde günlük yaşam içinde yapılan aktivitelerin daha çok bacaklar üzerinde yoğunlaştı̆̆ı ve bunun sonucunda yaşlanma sürecinde kol kuvvetinin azalmasının daha muhtemel olduğu varsayılabilir. Aynı şekilde artan vücut ağırllğının hareket sınırlamasına neden olarak bacak kuvveti ve kol kuvvetinin gelişmesini olumsuz etkileyebileceği düşünülmektedir.

Aerobik dayanıklılığı değerlendirmek için iki dakikalık diz çekme testi uygulanmıştır. Aerobik dayanıklılığın yürüyüşe çıkmak, alışverişe gitmek, bahçe işlerini yapmak gibi günlük aktivitelerde gerekli olduğu düşünülmektedir. Elde edilen veriler Almanya örnekleminin normal kilolu ve fazla kilolu kadınlarda ve fazla kilolu erkeklerde ABD örnekleminden daha düşük değerlere ulaştıklarını gösterirken, 60-64, 65-69 ve 70-74 yaş aralığındaki normal kilolu erkeklerin ölçüm değerlerinin ABD örnekleminden daha yüksek olduğunu göstermektedir (Rikli ve Jones, 1999b; Jones ve Rikli, 2002b). Almanya'da yapılan benzer bir çalışmada Aksay (2021) yaşları 60-89 arasında olan 354 yaşlı yetişkin bireye 50 haftalık rehabilitasyon sporu programı uygulayarak ön test/son test karşılaştırması ile performans değişimlerini belirlemeye çalışmış ve çalışma sonrasında ölçüm değerlerinin yükseldiğini rapor etmiştir. Aksay’ın (2021) çalışmasındaki ön test değerleri bu çalışmadan negatif yönde farklılık gösterirken, çalışma sonrasındaki değerleri bu çalışma ile paralellik göstermektedir. Genel olarak iki dakikalık diz çekme testi sonuçları normal kilolu bireylerin lehine istatiksel olarak anlamlı farklılık göstermektedir. Bu sonuçlardan yola çıkarak fazla kilonun aerobik dayanıklılık kapasitesini olumsuz etkileyerek günlük aktivitelerin yapılmasını zorlaştırdığı ve buna bağlı olarak sonuçların anlamlı şekilde farklılık gösterdiği söylenebilir. Yaşlı yetişkinlerde fazla kilo ve fiziksel aktivite arasındaki ilişkiyi analiz eden Newton ve diğerleri (2009), 45 fazla kilolu ve 88 normal kilolu kadının değerlerini karşılaştırdığı çalışmalarında fazla kilolu kadınların ölçüm değerlerinin daha düşük olduğunu ve buna bağlı olarak özellikle günlük aktivitelerin uygulanması ile ilgili sorunlar yaşandığını belirlemişlerdir (Newton ve diğ., 2009). Bu verilerden yola çıkarak yapılan bu çalışmadaki fazla kilolu ve normal kilolu bireylerin ölçüm değerlerinin düşük olmasının günlük aktiviteleri olumsuz etkileyec eği sonucuna ulaşılabilir.

Çeviklik ve dinamik denge becerisini değerlendirmek için 2,45 m uzaklığa git-gel testi uygulanmıştır. Çeviklik ve dinamik denge ani yön değiştirmelerde, otobüs ve metroya biniş ve inişlerde, ev içindeki kısa mesafeli hareketlerde gerekli olduğu düşünülmektedir. Elde edilen verilerden normal kilolu ve fazla kilolu katılımcılar arasında istatiksel farklılık olduğu sonucuna varılmıştır. Bu fark cinsiyetler arasında da istatiksel olarak anlamlıdır. Elde edilen verilere dayanarak normal kilolu bireylerin ABD (Jones ve Rikli, 2002b; Rikli ve Jones, 1999b), Slovakya (Kostić ve diğ. 2011), ve Norveç'te (Langhammer ve Stanghalle, 2018) yapılan benzer çalışmalardaki bireylere göre daha hızlı oldukları sonucuna ulaşılmıştır. Bu çalışmadaki normal kilolu bireylerin ölçüm değerleri diğer çalışmalardan farklılık 
Yaşlı Yetişkinlerde Fonksiyonel Uygunluk: 60 - 94 Yaş Arası Normal ve Fazla Kilolu Yaşlı Yetişkinlerin

Fonksiyonel Uygunluklarının Karşılaştırılması

Functional Fitness for Older Adults: Comparison of Functional Fitness of Normal Weight and Overweight

Older Adults between the ages of 60-94

göstermektedir. Bu farklılık yapılan bir önceki 2 dakika diz çekme testinden elde edilen ölçüm değerlerinin düşük olması ile ilişkilendirilebilir. Diz çekme testinde bireylerin çok fazla yüklenmedikleri ve bu durumun akabinde yapılan 2,45 m uzaklığa git-gel testine olumlu yansıdığı düşünülmektedir.

Esneklik değerlendirilmesi için alt vücut ve üst vücut esnekliğini ölçmeye yönelik otur-uzan ve sırt kaşıma testleri uygulanmıştır. Otur uzan testi günlük hayatta ihtiyacı duyulan ayakkabı giyme, çömelme, araca inip binme, yere uzanma ve kalkma; omuz esnekliğinin banyo yapma, saç yıkama ve tarama, pencere temizleme, yüksek raftan herhangi bir cisim alma, emniyet kemeri bağlama vb. aktiviteler için önemli olduğu düşünülmektedir. Elde edilen verilerden normal kiloluların fazla kilolulara oranla daha esnek oldukları ve sonuçların normal kilolu bireylerin lehine istatiksel olarak anlamlı farklılık gösterdiği belirlenmiştir. Bu fark cinsiyetler arasında da istatiksel olarak anlamlıdır. Esneklik gelişimine bağlı olarak 60 yaş üzeri yaşlı yetişkinlerle yapılan bazı çalışmalarda esneklik değerlerinin düşük olduğu gözlemlenmiştir (Dunn ve diğ., 2017; Eichberg ve Mechling, 2009; Langhammer ve Stanghalle, 2011; Pandey, 2016). Bu çalışmada 6064, 65-69 ve 75-79 yaş grubundaki normal kilolu ve fazla kilolu kadın ve erkeklerin otur-uzan testinde diğer çalışmalardaki katılımcılardan daha esnek oldukları belirlenirken, diğer yaş gruplarında esnekliğin daha düşük olduğu gözlenmiştir. Bu sonuçlar her iki yönüyle diğer çalışmalardan farklılık göstermektedir (Aksay, 2021; DOSB, 2016; Kostić ve diğ., 2011; Langhammer ve Stanghalle, 2018). Sırt kaşıma testinde ise elde edilen veriler bu çalışmadaki 60-64 ve 6569 yaş aralığındaki normal kiloluların esneklik özelliğinin ABD örneklemiyle karşılaştırılabilir olduğunu gösterirken, fazla kiloluların esneklik özelliğinin ABD örnekleminden daha düşük olduğunu göstermektedir (Rikli ve Jones, 1999b). Yapılan benzer çalışmada Aksay (2021) omuz esnekliğinin daha düşük olduğunu belirtirken, Kostić ve diğerleri (2011) yaptıkları çalışmada omuz esnekliğinin oldukça yüksek olduğunu belirtmişlerdir. Bu noktada yapılan çalışmamız diğer çalışmalardan farklılık göstermektedir (Aksay, 2021; Kostić ve diğ., 2011). Bu farklıllığın örneklem grubumuzu rehabilitasyon sporu reçetelendirmesi yapılan bireylerin oluşturmasından kaynaklanabileceği düşünülmektedir.

Genel olarak yapılan testlerin tamamında ilerleyen yaş ile performansın anlamlı şekilde düştüğü görülmektedir. Bu farkl1lık gruplar, cinsiyetler ve yaş grupları arasında anlamlıdır. Yapılan çalışmalarda yaşlanma sürecisin 25-30 yaşlarında başlayıp, 75-85 yaşlarına kadar devam edebileceği ve bu süreçte fiziksel işlev kayıplarının artacağı bildirilirken (Halvorsrud ve Kalfoss, 2007; Laake, 2003), ilerleyen yaş ile beraber performansın düşeceği belirtilmiştir (Aksay, 2021; Aksay ve Güngörür, 2019; Dunn ve diğ., 2017; Jones ve Rikli, 2002b; Rikli ve Jones, 1999b; Langhammer ve Stanghalle, 2018; Langhammer ve Stanghalle, 2011). Bu çalışmanın sonuçları diğer çalışmalar ile paralellik göstererek testlerin tamamında kuvvet, dayanıklılık, beceri ve esneklik özelliklerinde yaş ilerledikçe beklenildiği üzere performansın düştüğünü ve özellikle performans kaybının 70 yaşından sonra daha da yükseldiğini göstermiştir. Yaşlanmanın \%30'unun kişinin elinde olmayan biyolojik sebeplere, \%70'inin ise yaşam şekline bağlı olarak değişim gösterdiği düşünüldüğünde (Kosel ve Froböse 1999), yapılan çalı̧̧maların birbirinden farklı sonuçlar göstermesinden performans kayıplarının sadece biyolojik sebeplerden değil, yaşa uygun fiziksel aktivitelere katılımdaki eksikliklerden kaynaklandığı varsayılmaktadır.

$\mathrm{Bu}$ çalışmada elde edilen test sonuçları norm değerleri ile karşılaştırıldığında fazla kilolu olan bireylerin testlerin tamamında norm değerlerinin altında kaldığı görülmektedir. Elde edilen verilerden fazla kilolu erkeklerin fazla kilolu kadınlara göre daha yüksek ölçüm değerlerine ulaştıkları ve erkeklerin kadınlara oranla norm değerlerine olan eğilimlerinin daha fazla olduğu belirlenmiştir. Elde edilen değerler bu çalışmadaki normal kilolu kadınların ABD örneklemindeki kadınlarla ile karşılaştırılabilir olduğunu gösterirken, fazla kilolu kadınlarda negatif yönde farklılık göstermektedir (Rikli ve Jones, 1999b). 60-64 ve 65-69 yaş grubundaki normal kilolu erkekler ise ABD örnekleminden daha yüksek değerlere ulaşmış, diğer yaş gruplarında ise ABD örneklemi ile karşılaştırabilir düzeyde performans sergilemişlerdir (Rikli ve Jones, 1999b). Aksay (2021) fazla kilolu olan benzer bir örneklem grubuyla yaptığ çalı̧̧mada 
katılımcıları deney ve kontrol grubu olarak ayırmıs ve deney grubuna 50 haftalık rehabilitasyon sporu programı uygulamıştır. Yapılan ön testte her iki grubun norm değerlerine ulaşamadığını, program sonrası deney grubundaki bireylerin testlerin büyük çoğunda norm değerlerine ulaştıklarını belirlemiştir. Bu çalışmada normal kilolu bireylerden ölçüm değerleri Aksay’ın (2021) ön test sonuçlarından farlılık göstermektedir. Bu farklılığın çalışmamızdaki örneklem grubunun VKİ değerlerinin daha düşük olduğundan kaynaklandığı düşünülmektedir.

\section{SONUÇ VE ÖNERILLER}

Sonuç olarak 60-94 yaş arası yaşlı yetişkinlerin VKİ değerleri ve yaş ile otur-kalk, kol bükme, diz çekme, otur-yürü, otur-uzan, omuz esnekliği gibi SFT alt testleri arasında anlamlı ilişki olduğu saptanmıştır. Normal kilolu bireylerin fazla kilolu bireylere oranla yapılan testlerin tamamında daha yüksek değerlere ulaştığı, kadınların esneklik gerektiren testlerde, erkeklerin ise kuvvet ve dayanıkl1lı gerektiren testlerde daha yüksek performans sergiledikleri ve ilerleyen yaş ile beraber her iki gruptaki kadın ve erkeklerin performanslarının düştüğü görülmüştür. Ek olarak fazla kilolu olan bireylerin testlerin tamamında norm değerlerinin altında kaldığı, normal kilolu erkeklerin bazı testlerde norm değerlerine ulaştıkları ve kadınlara oranla norm değerlerine olan eğilimlerinin daha fazla olduğu belirlenmiştir.

Yapılan bu çalışmada katılımcılar reçetelendirilmiş rehabilitasyon sporu programına katılan bireyler ile sınırlandırılmıştır ve katılımcıların sosyal statüleri ile ilgili bilgi toplanmamıştır. Bu nedenle gelecekteki çalışmalarda testin daha geniş örneklem grubuna uygulanmasının ve eğitim durumu, gelir düzeyi, meslek, yaşanılan bölge vb. sosyal statü ile ilgili bilgiler toplanarak değerlendirilmesinin farklı sonuçlar vereceğine inanılmaktadır.

\section{Yazar Katkısı (Author contributions):}

1. Ebubekir AKSAY: Fikir/Kavram, Tasarım, Denetleme, Veri Toplama ve/veya İşleme, Analiz-Yorum, Makale Yazımı, Eleştirel İnceleme

\section{Etik Kurul İzni ile İlgili Bilgiler}

Kurul Adı: Almanya TV Eberbach e.V. Sağlık, Rehabilitasyon ve Engelli Sporla Araştırmaları Kurulu

Tarih: 08.04 .2019

Sayı No: TVE/GS 2019-021 


\section{KAYNAKÇA}

1. Abdullah, A., Peeters, A., De Courten, M., ve Stoelwinder, J. (2010). The magnitude of association between overweight and obesity and the risk of diabetes: a meta-analysis of prospective cohort studies. Diabetes Research and Clinical Practice, 89(3), 309-319.

2. Aksay, E. (2021). Rehabilitasyon Sporunun Yaşlı Yetişkinlerin Performans Düzeylerine Etkilerinin Senior Fitness Test ile Belirlenmesi. Gazi Beden Eğitimi ve Spor Bilimleri Dergisi, 26(2), 247-264.

3. Aksay, E., ve Göngörür, Ö. (2019). Rehabilitasyon Sporlarının Yaşlı Bireylerin Performans Düzeylerine Etkileri. 17. Uluslararası Spor Bilimleri Kongresi. Antalya.

4. Aksay, E. (2013). Do simple warning signs enhance the use of stairs? Health Education Journal, 73(6), 683-692.

5. Allmer, H. (2005). Physical activity and cognitive functioning in aging. Journal of Public Health, 13(4), 185-188.

6. Baumgartner, T.A., Jackson, A.S., Mahar, M.T., Rowe, D.A. (2007). Measurement for evaluation in physical education and exercise science (8th ed.). Boston: McGraw-Hill.

7. Chmelo, E.A., Crotts, I.C., Newman, J.C., Brinkley, T.E., Lyles, M.F, Leng, X., Marsh, A.P., ve Nicklas, B.J. (2015). Heterogeneity of physical function responses to exercise training in older adults. Journal of the American Geriatric Society, 63, 462-469.

8. Chodzko-Zajko, W.J., Proctor, D.N., Fiatarone, M.A., Singh, M.D., Minson, C.T., Nigg, C.R., Salem, G.J., ve Skinner, J.S. (2009). Exercise and physical activity for older adults. Medicine \& Science in Sports \& Exercise, 41, 7, 1510-1530.

9. Cohen, J. (1988). The analysis of variance. In Statistical Power Analysis for the Behavioral Sciences (second ed.). Lawrence Erlbaum Associates. New York.

10. Conzelmann, A., ve Blank, M. (2009). Entwicklung der Ausdauer. Baur J, Bös K, Conzelmann A, Singer R, (Ed.). Handbuch motorische Entwicklung. $2^{\text {nd }}$ ed. Schondorf: Hofmann.

11. Davi, G. (2018). Alzheimer's disease in physicians - assessing professional competence and tempering stigma. The New England Journal of Medicine, 378, 1073-5.

12. Deutscher Olympischer Sportbund. (2016). Der Alltags-Fitness-Test. Deutsches Übungs-leitermanual. DOSB e.V. Geschäftsbereich Sportentwicklung: Frankfurt am Main.

13. Dunn., A., Marsden, D.L., Van Vliet, P., Spratt, N.J., ve Callister, R. (2017). Independently ambulant, community-dwelling stroke survivors have reduced cardiorespiratory fitness, mobility and knee strength compared to an age- and gender-matched cohort. Top Stroke Rehabilitation, 24(3),163-69.

14. Eichberg, S., ve Mechling, H. (2009). Motorische Entwicklung im höheren Erwachsenenalter. Baur, J., Bös, K., Conzelmann, A., Singer, R. (Ed.). Handbuch motorische Entwicklung (s. 333-348). Schorndorf: Hofmann Verlag.

15. Fiatrone, M.A., Marks, E.C., Ryan, N.D., Meredith, C.N., Lipsitz, L.A., ve Evans, W.J. (1990). High-intensity strength training in nonagenarians. Effects on skeletal muscle. The Journal of American Medical Association, 263, 3029-3034.

16. George, D., ve Mallery, M. (2010). SPSS for Windows Step by Step: A Simple Guide and Reference, 17.0 update (10a ed.) Pearson, Boston.

17. Granacher, U., Gruber, M., ve Gollhofer, A. (2009). Resistance training and neuromuscular performance in seniors. International Journal of Sports Medicine, 30(9), $652-657$.

18. Guh, D.P., Zhang, W., Bansback, N., Amarsi, Z., Birmingham, C.L., ve Anis, A.H. (2009). The incidence of co-morbidities related to obesity and overweight: a systematic review and meta-analysis. BMC Public Health, 9:88

19. Halvorsrud, L., ve Kalfoss, M. (2007). The conceptualization and measurement of quality of life in older adults: a review of empirical studies published during 1994-2006. European Journal Ageing 4, 229-246.

20. Holviala, J.H., Sallinen, J.M., Kraemer, W.J., Alen, M.J., ve Häkkinen, K.K. (2006). Effects of strength training on muscle strength characteristics, functional capabilities, and balance in middle-aged and older women. Journal of Strength and Conditioning Research, 20(2), 336-344.

21. Jones, C.J., ve Rikli, R.E. (2002a). Senior fitness test manual. Journal of Aging and Physical Activity.10(1), 110.

22. Jones, C.J., ve Rikli, R.E. (2002b). Measuring functional fitness of older adults. Journal on Active Aging, 1(2), 24-30.

23. Kilmen, S. (2015). Eğitim araştırmacıları için SPSS: Uygulamalı istatistik. Edge Akademi Yayıncılık: Ankara

24. Kosel, H., ve Froböse, I. (1999). Rehabilitations- und Behindertensport. 2., völlig neu überarbeitete Auflage, neue Ausgabe. Pflaum. München

25. Kostić, R., Pantelić, S., Uzunović, S., ve Djuraskovic, R. (2011). A comparative analysis of the indicators of the functional fitness of the elderly. The Facta Universitatis Series Physical Educatin and Sport, 9(2),161-171.

26. Kubesch, S. (2007). Das bewegte Gehirn Körperliche Aktivität und exekutive Funktionen. Schorndorf: Hofmann. 
27. Kurth, B.M. (2012). Erste Ergebnisse aus der „Studie zur Gesundheit Erwachsener in Deutschland“ (DEGS) Bundesgesundheitsblatt Gesundheitsforschung - Gesundheits-schutz, 55(8), 980-990.

28. Laake, K. (2003). Geriatri i praksis (Geriatrics in practice). 4th edn., Gyldendal Akademisk: Oslo.

29. Langhammer, B., ve Stanghelle, J.K. (2018). Senior fitness test; a useful tool to measure physical fitness in persons with acquired brain injury, Brain Injury, 33(2), 183-188.

30. Langhammer, B., ve Stanghelle, J.K. (2011). Functional fitness in elderly Norwegians measured with the senior fitness test advances in physiotherapy. Advances in Physiotherapy, 13(4), 137-144.

31. Loellgen, H., ve Loellgen, D. (2011). Risikoreduktion kardiovaskulärer Erkrankungen durch körperliche Aktivität. Der Internist, 53, $20-9$.

32. Macaluso, A., ve De Vito, G. (2004). Muscle strength, power and adaptations to resistance training in older people. European. Journal of Applied. Physiology, 91(4), 450-472.

33. Mahar, M.R., ve Rowe, D.A. (2008). Practical guidelines for valid and reliable youth fitness testing. Measurement in Physical Education and Exercise Science, 12(3), 126-145.

34. Mason, R.C., Horvat, M., ve Nocera, J. (2016). The effects of exercise on the physical fitness of high and moderate-low functioning older adult women. Journal of Aging Research, 2016(ID:8309284), 1-7.

35. Mensink, G.B., Schienkiewitz, A., Haftenberger, M., Lampert, T., Ziese, T., ve Scheidt-Nave, C. (2013). Overweight and obesity in Germany: results of the German Health Interview and Examination Survey for Adults (DEGS1). Bundesgesundheitsblatt Gesundheitsforschung Gesundheitsschutz, 56(5-6), 786-94

36. Morrow, J.R., Jackson, A.W., Disch, J.G., ve Mood, D.P. (2011). Measurement and evaluation in human performance (4th ed.). Champaign, IL: Human Kinetics.

37. Newton, R.U., Häkkinen, K., Häkkinen, A., McCormick, M., Volek, J., ve Kraemer, W.J. (2002). Mixed-methods resistance training increases power and strength of young and older men. Medicine and Science in Sports Exercise, 34(8), 1367-1375.

38. Oswald, W.D., Gunzelmann, T., Rupprecht, R., ve Hagen, B. (2006). Differential effects of single versus combined cognitive and physical training with older adults: the SimA study in a 5- year perspective. European Journal of Ageing, 3, 179-192.

39. Pandey, A, Patel, M.R., Willis, B., Gao, A., Leonard, D., Das, S.R. ve Berry, JD. (2016). Association between midlife cardiorespiratory fitness and risk of stroke: the cooper center longitudinal study. Stroke, 47(7), 1720-26.

40. Puthoff, M.L, ve Nielsen, D.H. (2007). Relationships among impairments in lower-extremity strength and power, functional limitations, and dis- ability in older adults. Physical Therapy, 87(10), 1334-1347.

41. Rikli, R.E., ve Jones, C.J. (2013a). Senior fitness test manual (2. Aufl.). Champain, USA: Human Kinetics.

42. Rikli, R.E., ve Jones, C.J. (2013b). Development and validation of criterion-referenced clinically relevant fitness standards for maintaining physical independence in later years. Gerontologist, 53(2), 255-67.

43. Rikli, R.E., ve Jones, C.J. (1999a). Development and validation of a functional fitness test for community-residing older adults. Journal of Aging and Physical Activity, 6, 127-159.

44. Rikli, R.E., ve Jones, C.J. (1999b). Functional fitness normative scores for community-residing adults, ages 60-94. Journal of Aging and Physical Activity, 6, 160-179.

45. Roaldsen, K., Halvarsson, A., Sahlstrom, T., ve Stahle, A. (2014). Task-specific balance training improves selfassessed function in community-dwelling older adults with balance deficits and fear of falling: a randomized controlled trial. Clinical Rehabilitatin, 28(12), 11891197.

46. Rowe, J.W., ve Kahn, R.L. (1997). Successful aging. Gerontologist, 37(4), 433-40

47. Schienkiewitz, A., Mensink, G.B.M., Kuhnert, R., ve Lange, C. (2017). Übergewicht und adipositas bei erwachsenen in Deutschland. Journal of Health Monitoring, 2(2), 21-28.

48. Sherrill, D.L., Kotchou, K., ve Quan, S.F. (1998). Association of physical activity and human sleep disorders. Archives of Internal Medicine, $28 ; 158(17), 1894-8$.

49. Statistisches Bundesamt. (2019). Annahmen und Ergebnisse der 14. koordinierten Bevölkerungsvorausberechnung - Bevölkerung im Wandel. Statistisches Bundesamt: Wiesbaden.

50. Wessel, K., ve Hummel, A. (2019). Bewegung und Sport als alternsstabilisierende Aktivi-täten. Zeitschrift für Gerontologi und Geriatrie, 52, 290-291.

51. Wollny, R. (2002). Motorische entwicklung in der lebens- spanne: warum lernen und optimieren manche menschen bewegungen besser als andere? Schorndorf: Hofmann.

52. World Cancer Research Fund/American Institute for Cancer Research (2007). Food, Nutrition, Physical Activity, and the Prevention of Cancer: a Global Perspective. AICR, Washington DC.

53. World Health Organization (2013). Global action plan for the prevention and control of NCDs 2013 - 2020. WHO. Geneva. 
Yaşlı Yetişkinlerde Fonksiyonel Uygunluk: 60 - 94 Yaş Arası Normal ve Fazla Kilolu Yaşlı Yetişkinlerin Fonksiyonel Uygunluklarının Karşılaştırılması

Functional Fitness for Older Adults: Comparison of Functional Fitness of Normal Weight and Overweight Older Adults between the ages of 60-94

54. World Health Organization (2000). Obesity: preventing and managing the global epidemic. WHO. Technical Report Series 894. Geneva

55. Zimmermann, K. (2000). Gesundheitsorientiertes muskelkrafttraining: Theorie, empirie, praxisorientierung. Schorndorf: Hofmann. 